ISSN: 2716-1277

e-ISSN: 2716-1269 TIC https://jlic.iain-jember.ac.id/
Journal of Language Intelligence and Culture

Fakultas Tarbiyah dan Ilmu Keguruan

IAIN Jember

Vol. 2, No.2, 126-140, December 2020

\title{
The Development of Learning Media "E-Writing" to Develop Students' Writing Skill of English Education Department
}

\author{
Ninuk Indrayani, \\ IAIN Jember \\ ninukindrayani@gmail.com
}

\section{ARTICLE INFO}

\section{Article History:}

Accepted: November, $5^{\text {th }} 2020$

Approved: December, $17^{\text {th }} 2020$

Published: December 2020

Key Words:

Media Development, Media E-Writing, Writing Skill,

DOI: $10.35719 / j l i c . v 2 i 2.31$

\begin{abstract}
This study aimed at developing an appropriate electronic learning media named E-Writing to improve students' writing skill of English Education Department. This media will be the solution of students' difficulties in writing activities especially as a guidence for writing task and activities. That is why this research is going to develop a media which based on the needs of analysis to make the learning process of writing skill become effective. This research is developed based on the Design and Development (D\&D) model. The data obtained from the experts' evaluation result. All data are both analyzed qualitatively and quantitatively using mean score and alpha Cronbach formula. The result of this study suggested that EWriting can be such a beneficial media for students' writing development.
\end{abstract}

\section{INTRODUCTION}

Writing skill are one of the language skills that play an important role in teaching and learning English. Having writing skills helps someone to communicate or convey ideas and ideas in communicating (Brown, 2007). In addition, Tadris Bahasa Inggris (TBI) students really need adequate writing skills because one of the requirements for their graduation is determined from the results of their final writing in the form of a thesis. In completing the final project, TBI students are not only required to be able to 
present brilliant ideas, but also with correct grammar and language style according to the rules of writing in English.

As is well known, writing skills are a means of written communication which have been claimed to be the most difficult of the four language skills. This assumption is because the writing process takes a long time and is complicated (Harmer, 2004), and in its completion it requires language components that include good vocabulary and grammar through adequate reading and listening skills.

A good writing process must go through several procedures, namely planning, compiling, and editing, even re-planning, rearranging, and re-editing before they produce the final version of the written product. Based on the pre-research survey, TBI students did not carry out the writing procedure and preferred to go to the instant line by directly writing according to what came to their mind, resulting in poor written works.

In addition, according to Brown (2004) a good written product must meet several writing criteria; including organization, content, grammar, vocabulary, and mechanics. Based on the preliminary study done, it was found that the TBI students of IAIN Jember had difficulty writing in English, which included poor organization, unstructured content, wrong grammar, word choice, and mechanics; such as incorrect spelling, capitalization, and punctuation. Most of the obstacles faced by TBI students are difficulties in grammar and in choosing the appropriate vocabulary in English. Of course, this deficiency has fatal consequences in the quality of their writing.

Apart from the above factors, students are also faced with the problem of limited time. The writing process takes time to compose ideas, compose writing and then, review and edit them in various ways especially if needed, changing ideas, rearranging, reediting, and so on, and the whole process certainly cannot be done in 15 minutes.

In order to overcome these difficulties, the best solution should be found so that the learning process in writing skills can be carried out properly. Apart from paying attention to the material, strategies and learning environment, of course what can be pursued is to use learning media.

It must be admitted that the development of learning media for learning writing skills is still very limited in number. The media 


\section{JLIC}

that are usually used are usually only a series of pictures or videos that are only in the form of providing a stimulus to stimulate the reasoning process and develop writing ideas only. There is no learning media that can guide learners in a comprehensive manner starting from idea development, organization to final results. So that the presence of effective and efficient learning media is increasingly needed.

Effective, of course, refers to how the learning media is able to accommodate all the problems commonly encountered by learners in class such as the structure and organization of texts, development of ideas, vocabulary, grammar and even revisions and publications. Efficient, of course, refers to that the learning media must be able to be used with due regard to all the limitations of both time and facilities.

For this reason, this study aims to develop a learning media to improve the writing skills of learners, especially students of TBI at IAIN Jember, with an emphasis on three aspects, namely design, development, and quality of E-Writing learning media. This learning media will be electronic-based interactive learning media that can help students overcome difficulties in the learning process of writing skills. This media is designed to help learners write in various text structures, help students develop ideas, check vocabulary and is equipped with pair revision and group revision features which can be used to revise writing with input from other students and lecturers. Most importantly, this media can be used with tutor guidance or independently because it is user friendly. In addition, this learning media can be applied to laptops or cellphones so that it can be used anytime and anywhere.

\section{METHODS}

This research can be categorized as Design and Development. This refers to the design and development of a product using a 6-phase model, namely: a) identifying the problem that motivates research; b) describe the objectives; c) designing and developing artifacts; d) the subject of the artifact for testing; e) evaluate the test results; and f) communicating the results. The research design framework can be seen as follows: 


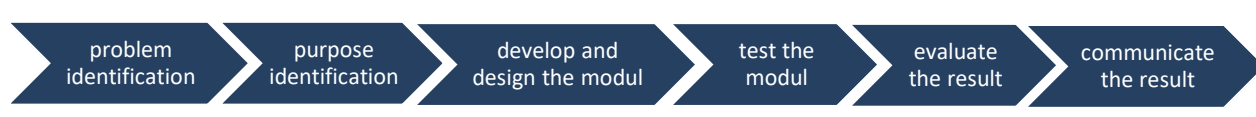

Figure 1. Research Model Design and Development

Problem identification was carried out at the beginning of the study. The problem is the lack of student writing competence. The purpose of the research was carried out after identifying the problem itself. The objectives of this study were: 1 ) to determine the design of E-Writing learning media to improve the writing competence of TBI students at IAIN Jember, 2) to identify the development of E-Writing learning media to improve TBI students of IAIN Jember's writing competence, and 3) to identify the quality of E-Writing learning media to improve the writing competence of TBI students of IAIN Jember. Thus, the design and development of instructional media will be carried out to meet these objectives.

Design and develop artifacts based on goals. In this case, the E-Writing learning media to improve the writing competence of TBI students at IAIN Jember are artifacts developed in this study. Designing and developing E-Writing learning media to improve the writing competence of TBI students at IAIN Jember with the text genre used in teaching writing competencies in general. Artifact testing is performed to find out whether the developed artifact fulfills the functions and requirements assigned to it during the design and development stages. Validation sheets and expert assessments are instruments used to check whether the artifact has fulfilled these aspects or not.

Evaluation will be the next stage because it is an important part of making decisions about the testing conducted by the experts whether the product needs to be revised or not.

After all the tests have been completed, the final step is to communicate the test results. In this case, the communication is carried out after the test results will be carried out by the expert. This is also an important step where comments and input are obtained for the advancement of the product as they will be used as instruments for future research.

This type of research is development research. Development research is research that aims to produce or develop a product. According to Gay (1987), development research is an effort to develop an effective product for school use, and not to test theory. 


\section{JLIC}

Meanwhile, according to Borg \& Gall (1989), research and development is a process used to develop and validate educational products.

A number of instruments are used to assist researchers in collecting data for this study. The types of instruments used by researchers in collecting data are:

\section{Conceptual Model / Syllabus}

The first instrument used in conducting this research was a collection of teaching writing competency themes.

\section{Checklist}

According to Patton (2003), the purpose of the checklist is to guide evaluators in (1) choosing a qualitative approach that is particularly suitable for the intended use of evaluation and answering evaluation questions, (2) collecting quality and credible qualitative evaluation data, and (3) analyzing and reporting findings qualitative evaluation.

A checklist (checklist) can be used as an instrument to evaluate research results. The checklist instrument that will be used in this study consists of several items or criteria as an evaluation of the learning media that will be developed by the researcher. The checklist will be used by the expert to find out whether the learning media to be developed can be applied or not.

\section{Expert validation sheet}

Expert judgment is an expression of opinion based on information, based on knowledge and experience which according to experts is in accordance with technical issues. Experts are recognized and qualified persons who are qualified to solve technical problems (Booker, 2001). Expert assessment is used in this study to assess or evaluate the E-Writing learning media to improve the writing competence of TBI students at IAIN Jember who will be developed. Expert judgment will be very strong as an evaluator to validate research data.

Using expert judgment in a study must consider several criteria to make the study reliable and valid. The criteria for evaluating experts in this study are the first, at least two experts (Helmer, 1963). There are two ways in which expert groups can be 
used. One is individual expert judgment, and the other is having them work together in groups and carry out assessments.

Experts in this research, of course, must be people who are concerned with the development of education and also have high competence regarding the teaching and learning process, especially teaching English.

The data collection method consists of three main steps, namely 1) artifact design and development, 2) artifact testing, and 3) and evaluation of test results. The design and development of artifacts begins with designing and developing artifacts by surveying documents related to instructional media. Next, the artifacts are tested by experts to check their applicability. A clear explanation of each step will be presented as follows:

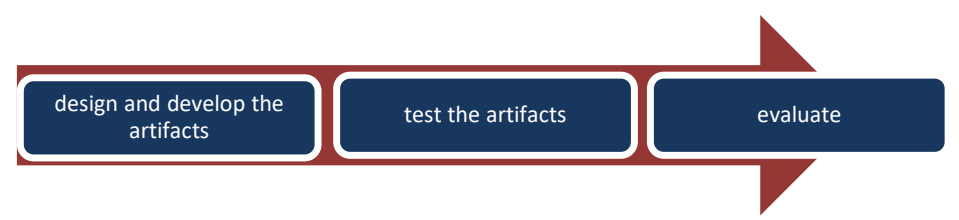

Figure 2. Data Collection Procedure

\section{Artifact Design and Development}

The learning syllabus is used as a basis for designing and developing E-Writing instructional media to improve the writing competence of TBI students at IAIN Jember. The media will be designed and developed by considering several factors, such as: learning material in the syllabus, genre of text, and also the criteria for good learning media

\section{Artifact Test}

After being designed and developed, the instructional media will undergo expert judgment to be examined before its application in the classroom. The test is carried out by providing a checklist sheet and a validity form for expert judgment.

\section{Evaluation of Test Results}

Evaluation is carried out as the last step to reflect the test results in order to make the right decisions about the product. Final revision is important here to ensure there are no errors in the product so that it can be used for future research. 


\section{JLIC}

The data will be analyzed descriptively. Descriptive statistics will be used for expert validation sheet data which includes three components, namely content, appearance, and language. Tabulation and data reduction are used to classify data from expert test results to determine whether to obtain data analysis as a research report.

The scores from experts who evaluate the quality of textbooks will be analyzed by calculating the average of each expert test result for each component, namely content, appearance, and language. The formula used to calculate the average for each expert will use the following formula:

$$
\text { Experts score }\left(\bar{x}_{\text {expert }}\right)=\frac{\text { total score }\left(\sum x\right)}{\text { total experts }\left(\sum n\right)}
$$

Because this study will use 2 expert opinions for each aspect (content, appearance, language), the mean of each aspect will be calculated using the following formula:

$$
\text { the average of each aspect }\left(\bar{x}_{\text {aspect }}\right)=\frac{\bar{x}_{\text {expert } 1}+\bar{x}_{\text {expert } 2}}{2}
$$

To get the final score for the overall quality of teaching materials, the mean of all aspects of content, appearance and language will be calculated to obtain a single average using the following formula:

$$
\text { product score }\left(\bar{x}_{L M}\right)=\frac{\bar{x}_{\text {content }}+\bar{x}_{\text {appearance }}+\bar{x}_{\text {language }}}{3}
$$

The final score will be classified into a Likert scale which consists of several categories according to the score. Category classification can be seen in table 1.

\begin{tabular}{cc}
\hline Interval Skor & Kategori \\
\hline $0-1.0$ & Very Bad \\
\hline $1.1-2.0$ & Bad \\
\hline $2.1-3.0$ & Moderate \\
\hline $3.1-4.0$ & Good \\
\hline $4.1-5.0$ & Very Good \\
\hline
\end{tabular}

Table 1. Category Score Expert assessment 
After getting the results from the test results of the experts for product quality, the product was also analyzed for its reliability using the Alpha Cronbach formula through the SPSS software. A research instrument is reliable if its reliability level (r11)> .6o. The Alpha formula used is:

$$
\begin{aligned}
& r_{11}=\left[\frac{k}{k-1}\right]\left[1-\frac{\sum \sigma_{b}^{2}}{V_{t}^{2}}\right] \\
& \text { r11 }= \text { reliability } \\
& \mathrm{k}= \text { number of criteria } \\
&= \text { sample variant } \\
&= \text { variant of the total test score }
\end{aligned}
$$

Criteria are established to determine whether the study is successful or not. The success of this study is determined by several criteria, namely compliance with the syllabus, conformity with the criteria for a good instructional media component and also supported by the results of expert judgment whose minimum score must be in the interval 3.1-4.o (which is categorized as "good" from the interval 0.0-5.0) and if the Alpha reliability is above .6o. If all the criteria are met, the learning media can be categorized as suitable for use.

\section{RESULTS AND DISCUSSION}

As stated earlier, there are three objectives for this study. First, to find out the design of E-Writing learning media to improve writing competency accordingly. Second, to identify the development of E-Writing learning media to improve writing competence. Third, identify the quality of E-Writing learning media to improve writing competence. Based on these objectives, the research findings are discussed as follows:

\section{E-Writing Learning Media to Improve Appropriate Writing Competence}

This research is used to answer the problems of students in the English Tadris Study Program who have difficulty writing and developing ideas in writing. So online writing learning media was developed to complement the existing syllabus and present the steps for coherent writing activities from the four genres / types of writing taught in the RPS in writing courses in the TBI Study Program. 


\section{JLIC}

The syllabus and several criteria for good instructional media serve as guidelines for online media development. The accuracy of the media with the syllabus can be seen from an in-depth exploration of all the components of the syllabus and RPS, both from mind mapping and achievement indicators. The results of indepth exploration of the curriculum itself are then applied in media development which can be seen from the development of the genre / type of writing used in the media, the activities developed, the layout, images and language to support the learning process.

Learning media is also designed to meet the 8 criteria for good media by Bates, namely: 1) according to student needs, 2) easy to use, 3) easy to reach, 4) functioning well, 5) causing interaction, 6) being organized, 7) being able to connect parties related, 8) safe to use (Bates, 2012).

In addition, as with other technology-based media, the development of E-Writing media also refers to the criteria for good media according to Educational Development and Technology (2015), as follows: 1) has a good composition structure, 2) is easy to use by teachers and learners, 3) can help the learning process in explaining concepts and features, and 4) can help achieve learning objectives.

\section{Development of E-Writing Learning Media to Improve Writing Competence}

There are three major steps in developing instructional media. There are design and development, product testing and product evaluation. All stages are developed in a very good way to get high quality products, in this case E-Writing learning media to improve writing competence. Designing and developing a product includes all steps from preparation to construction. The first step that must be taken is to study the curriculum. The author explores each part of the syllabus to get an in-depth understanding of the basic standards and competencies stated in the syllabus to be applied in further textbooks. Curriculum analysis includes standard competency studies and basic competencies. The basic competencies are then distributed to several indicators and materials. Further identified subjects were mapped and compiled. The next step is to set goals for the learning process itself. Before developing instructional media, the writer needs to know the learning objectives of the course. By knowing this, the author can 
design what types of activities should be provided in the learning media to help students achieve the expected competencies of students in the curriculum.

After exploring the curriculum and student competencies, the next step is to select the materials and activities that will be provided in the media. This includes the genre / type of writing, the design of the activity steps, the layout and also the language that will be used in the media.

The next stage is to choose a genre / type of writing in learning media. This step includes the process of gathering material, generic structure, language features and examples of text used in the media, managing vocabulary variations, and also detailing the activities that will be presented in the media.

Developing learning materials is the next stage after the researcher is ready with all the preparations. This is the stage when the researcher arranges, matches and arranges the content of the learning media.

The development of learning media focuses on three main components, namely the content of the media, the layout and also the language used in textbooks. After completing the development of E-Writing media, the next stage is getting validation from experts. All stages carried out in the development of the E-Writing media meet the 6 main steps for development learning materials stated by the Ministry of National Education (2004), namely 1). Study the curriculum, 2). Determine the competencies of students / children that need to be achieved, 3). Select and arrange the material to be presented, 4). Select and arrange the type and study material, 5). Develop learning materials, and 6). Evaluation of learning materials. This shows that the development of this culturebased media is in accordance with the learning material development process standards stated by the Ministry of National Education. Even though the media is a product that offers a local cultural package, its development must be carried out in a standard form provided by the government.

\section{Quality of E-Writing Learning Media to Improve Writing Competence}

To find out the quality of the media, it is very important to test the E-Writing media and get validation for the quality of the media. E-writing media testing is done by asking two experts to 


\section{JLIC}

validate the media and asking for some comments or suggestions for revision or evaluation in the next step.

Testing includes the main components of the media such as content / activity content, media display layout / layout and language. As stated by Reddi and Mishra (2003), the use of interactive media in the teaching and learning process can provide benefits, namely: 1) enabling creative work 2) saving time 3) replacing ineffective learning activities and 4 ) increasing discussion time.

The validation test is done by asking experts to fill out an expert assessment questionnaire about the quality assessment of the E-Writing media. There are 3 main components such as content containing 8 validation items, layout containing 7 validation items and language containing 5 validation items. So the sum of all items is 20 items. The scale used in the checklist is $\mathbf{1}^{-5}$, which means very bad, bad, fair, good, very good.

After completing the textbook, the next step is to get validation from experts. The experts who validate this media are the Head of TBI Study Program and one of the lecturers who teaches the Writing course at TBI Study Program of IAIN, Jember. Validation is done by criticizing the E-Writing media based on three components: content, layout and language.

The result of the first expert is that 15 items are given a score of 4 which means good. However, there are some suggestions for revising the content and layout sections. The result of the second expert is that 17 items are given a score of 4 which also means good.

The results of the evaluation of expert assessments were then analyzed with a Likert scale and the average score of the evaluation results of expert assessments was 3.75, which means that the learning material developed was good learning material. The results were also analyzed with Alpha formula to determine the reliability of the product being developed. The score for Alpha analysis is 0.898 which means that the product being developed is reliable. All statistical results show that the E-Writing developed is an appropriate learning medium. All of the above statements show that the media is of good quality and the development of E-Writing learning media to improve writing competence is successful. 


\section{CONCLUSION}

The development of information technology has led to the integration of electronic media into English language teaching to create an attractive learning environment. The use of electronic media in teaching writing is expected to change students' motivation towards English learning and the teaching process and improve their writing skills and interest in writing. The integration of interactive electronic media in teaching writing is beneficial in improving the writing skills of learners. The media developed is expected to make the teaching and learning process of writing competency more interesting and lively. Good writing programs also allow students to work cooperatively and collaboratively.

\section{REFERENCES}

Alyani, Rochana. 2016. Developing Writing Materials by Using Genre-Based Approach for the First Semester Of The Tenth Grade Students At Sma Piri 1 Yogyakarta. Universitas Negeri Yogyakarta

Baoan. 2008. Application of Popular English Songs in EFL Classroom Teaching. HLT Magazine and Pilgrims. Year 10; Issue 3; June 2008, ISSN 1755-971

Barr Ebest, Sally. Changing the Way We Teach: Writing and Resistance in the Training of Teaching Assistants. Carbondale: Southern Illinois UP, 2005

Bates, Anthony. 2012. Choosing and Using Media in Education: The SECTIONS Model

Booker, Mayer. 2001. Elisitasi dan Analisis Pakar Borg, W. R. and Gall, M. D. 1989. Educational Research: An Introduction 5th. edn. NewYork: Longman.

Brewster, J., Ellis, G, \&Girard, D. 2007. The Primary English Teacher's Guide. Essex, England: Pearson Education Limited 


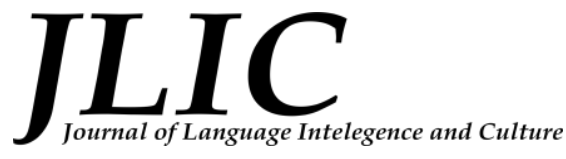

Brown, H.D. 2004. Language Assessment: Principles and Classroom Practices. New York: Pearson Education

Brown, H.D. 2007. Teaching by Principles: An Interactive Approach to Language Pedagogy (3rd edition). New York: Pearson Longman

CCSU. 2016. Worlds Most Littered Nation Ranked.

Coger, R. 1975. Developing Effective Instructional Systems. U.S.A.: The Christopher Publishing House

Cole, Michael. Cole, Sheila.R \& Lightfoot, Cynthia (2005). The Development of Children. New York: Worth Publishers

Conradie, P.J. 1977. Van Ondemghulpmiddel Tot Sisteemondenig. Durban: Butterworth

Ellis, TJ \& Levy, Y. 2010. Panduan untuk Peneliti Novice: Desain dan Metode Penelitian Pengembangan. Prosedur Menginformasikan Pengawasan Ilmu Pengetahuan dan Ilmu Pengetahuan (InSITE)

E. Shelley Reid. 2009. Teaching Writing Teachers Writing: Difficulty, Exploration, and Critical Reflection

Fabon. 2013. Use Songs to Teach English as a Second Language in Primary School. Universidad de La Rioja, Servicio de Publicaciones

Gay, L. R. 1987. Educational Research: Competencies for Analysis and Application: 3rd.edn. London: Merrill Publishing.

Harmer, J. 2004. How to Teach Writing. Essex: Pearson Education

Heinich, R., Molenda, M \& Russel, J.D. 1989. Instructional Media. London: Collier Macmillan

Helmer, Olaf. 1963. Penggunaan Pakar Pakar secara Sistematik dalam Riset Operasi 
Jacobs, M., Gawe, N. \& Vakalisa, N.C.G. 2002. Teaching-Learning Dynamics: A Participative Approach for OBE. 2nd edition. Johannesburg: Heinemann

Jafarian, K., Soori, A. \& Kafipour, R. 2012. The Effect of Computer Assisted Language Learning (CALL) on EFL High School Students' Writing Achievement. European Journal of Social Sciences. Vol.27

Langran, John \& Purcell, Sue. 1994. Language Games and Activities. Netword 2. Teaching Languages to Adults. London: Center for Information on Language

Marquardt, M.J. 1999. Action Learning in Action: Transforming Problems and People for World-Class Organizational Learning. Boston: Davies-Black

Mayer, R.E. \& Moreno, R. 2002. Aids to Computer-Based Multimedia Learning

Megarry, J., Walker, D.R.F., Nisbet, S. \& Hoyle, E. 1983. World Yearbook of Education 198213, Computers and Education. London: Kogan Page Ltd

Patton, Quinn. 2003. Daftar Periksa Evaluasi Kualitatif

Rahardjito. Haryono, Anung. Rahardjo, R. dan Arief, S. Sadiman. 2008. Media Pendidikan: Pengertian, Pengembangan, dan Pemanfaatannya. Jakarta: PT Raja Grafindo Persada.

Reddi, U.V. \& Mishra, S. 2003. Education Multimedia: A Handbook for TeacherDeveloper. New Delhi: The Commonwealth Educational Media Centre for Asia (CEMCA)

Reiser, A. Robert. 1996. Instructional Planning: A Guide for Teachers. USA: Library of Congress Catalog-in-Publication Data

Suhartono dan Laraswati. 2016. The Use of Visual Media in Teaching Writing. University of Nusantara PGRI Kediri 


\section{JLIC}

Vreken. An Introduction to Teaching-Learning Media. A Manual for Student Teachers

Wah, C.L. 2006. A Study of Students' Perceptions and Attitudes Towards ESL Writing Using Computer-Based Learning Materials. Internet Journal of ELanguage Learning $\mathcal{E}$ Teaching. Vol. 3

Warschauer, M. 1996. Computer-Assisted Language Learning: An Introduction. In S. Fotos (Ed.), Multimedia Language Teaching (pp. 3-20). Tokyo: Logos International

Wening, Rahayu.2016. The Role of Picture Series in Improving Students' Writing Ability. International Conference on Education. Universitas Negeri Malang

Zhu, Zhuo. 2010. Applying Innovative Spirit to Multimedia Foreign Language Teaching. English Language Teaching. Vol. 3 